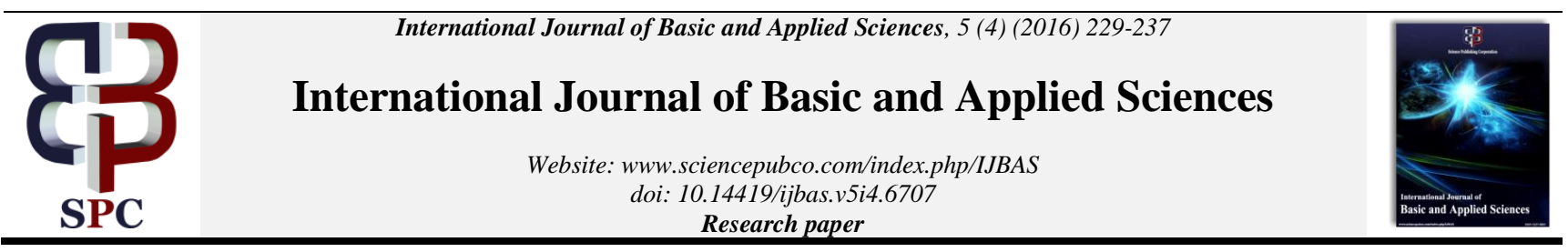

\title{
Relation between vitamins of the b complex, GABA and glutamate, and their role in neurocognitive disorders -Brief review
}

\author{
Rayssa Justo ${ }^{1,2}$, Marcelo Cesar ${ }^{1,2}$, Edimilson Migowski ${ }^{2,3}$, Rafael Cisne ${ }^{1,2}$ * \\ ${ }^{1}$ Dept. of Morphology, Biomedical Center, Fluminense Federal University, Niterói, RJ, Brazil \\ 2 Scientific Board, Vital Brazil Institute, Niterói, RJ, Brazil \\ ${ }^{3}$ Child Care and Pediatrics Institute Matagão Gesteira, Federal University of Rio de Janeiro, RJ, Brazil \\ *Corresponding author E-mail: rafael.cisne@gmail.com
}

\begin{abstract}
Vitamins, especially the water-soluble complex of vitamins B, are highlighted in the daily clinical practice. Numerous studies emphasize the need for supplementation, mainly in groups with deficiency of these vitamins, such as the elderly, pregnant women, children and patients with diseases associates with cognitive disorder. Thiamine (B1), a vitamin of the diet, is an important cofactor for the three key enzymes involved in the citric acid cycle and the pentose phosphate cycle. Pyridoxine (B6) and cobalamin (B12) act in the CNS as a cofactor in the metabolism reactions of homocysteine. Deficiency of some neurotransmitter precursors can also cause symptoms of attention deficit hyperactivity disorder in children, especially amino acid and vitamin B deficiency. Inhibitory and excitatory neurotransmitters regulate diverse behavioral processes, including sleep, learning, memory and sensation of pain. They are also implicated in many pathological processes, such as epilepsy and neurotoxicity. Studies suggest that the excitatory amino acids may play a role in learning and memory. The binding of glutamate to its receptor triggers molecular and cellular events associated with numerous physiological and pathophysiological pathways, including the development of an increased sensation of pain (hyperalgesia), brain neurotoxicity or synaptic alterations involved in certain types of memory formation. Between the two major classes of neuroactive amino acids, $\gamma$-aminobutyric acid (GABA) is the major inhibitory amino acid. It is known that GABA plays a fundamental role in encoding information and behavioral control, in the regulation of motor function and in motor learning. The inter-relationships between diet, the brain and behavior are complex. However, micronutrients are known to have a direct influence on cognitive function through their involvement in the energy metabolism of neurons and glia cells, the synthesis of neurotransmitters, receptor binding and the maintenance of membrane ion pumps.
\end{abstract}

Keywords: GABA; Glutamate; Vitamins B; Neuroplasticity; Neurotransmission.

\section{Introduction}

The inter-relationships between diet, the brain and behavior are complex. However, micronutrients are known to have a direct influence on cognitive function through their involvement in the energy metabolism of neurons and glia cells, the synthesis of neurotransmitters, receptor binding and the maintenance of membrane ion pumps. Vitamins have potential benefits for cerebral function, since their deficiencies are characterized by dramatic neurological manifestations. In the first part of this article, the current knowledge of the physiological roles of some vitamins of the B complex most closely associated with cognitive performance will be reviewed, with particular reference to the central nervous system (CNS). In the second part of this article, the physiological roles of two main neurotransmitters of the CNS are discussed as well.

\section{Vitamins B}

Vitamins, especially the water-soluble complex of vitamins B, are highlighted in the daily clinical practice. Numerous studies emphasize the need for supplementation, mainly in groups with deficiency of these vitamins, such as the elderly, pregnant women, children and patients with diseases associates with cognitive disorder [1], [2].

Clinical evidence shows that all B vitamins have a fundamental role in neurotransmitters, lipids and proteins metabolism, and act differently in various enzyme systems, participating as coenzymes in the activation of numerous metabolic processes [3], [4]. Demonstrations found in scientific papers related to B vitamins deficiencies are, mostly, neurological and cardiovascular [5]. Being water soluble, these vitamins are not considerably stored in the body, so that a daily supply through diet is critical to prevent deficiencies. The main sources of these vitamins are red meat [6].

\subsection{Thiamine}

Thiamine (B1), a vitamin of the diet, is an important cofactor for the three key enzymes involved in the citric acid cycle and the pentose phosphate cycle. Thiamine is vital to the maintenance of cellular oxidative metabolism and synthesis of nucleotides in the developing brain [7], [8] as well as in adults [9], [10].

The deficiency in cellular metabolism and oxidative stress in Alzheimer's disease is very similar to that induced by thiamine deficiency. Clinical and experimental evidences have demonstrated that patients with Alzheimer's disease also show a downregulation (low hippocampal neurogenesis) [11], besides dependent oxidative metabolism and reduced thiamine [12], [13]. Other experiments show that mice with deficiency of thiamine produce a pathological 
change Alzheimer's-like, with a selective neuronal loss [14]. Therefore, hippocampal neurogenesis is vulnerable to thiamine deficiency.

The hippocampus has been recognized as the structure related to learning and memory; it plays a key role in neural plasticity induced in physiological conditions as well as pathological conditions. The correlation between hippocampal neurogenesis and cognitive function naturally awakened enormous research interest [15], [16], [17]. Experimental evidence has shown that the newborn neurons in the hippocampal dentate gyrus have the potential to become synaptically integrated [18], [19], [20], [21] and achieving neuronal characteristics morphological, biochemical and electrophysiological normal [22], [23], [24].

Furthermore, thiamine plays an important role in the synthesis and decomposition of acetylcholine (Ach). Ach is synthesized in neurons from choline and acetyl coenzyme A (CoA) by the enzyme choline acetyltransferase. Acetyl-CoA is derived primarily from oxidative decarboxylation reaction of pyruvic acid. Thiamine pyrophosphate (TPP), an active type of thiamine, is a coenzyme key to this reaction of oxidative decarboxylation. The thiamine deficiency leads to inhibition of ACh synthesis due to the reduction of acetyl-CoA. Moreover, such a deficiency weakens the inhibitory effect of thiamine on the activity of acetylcholinesterase and accelerates the inactivation of Ach. Therefore, inhibition of ACh synthesis may contribute to cognitive dysfunction induced by thiamine deficiency [25]. All this functional mechanism is summarized in Figure 1.

Zhao et al. (2008) [25] explored the influence of thiamine deficiency (DT) in the pathological pre-injury stage in the early neurogenesis and the correlation between affected neurogenesis and cognitive dysfunction. The mouse experimental model DT was fed a diet with thiamine depletion. The functions of learning and memory of mice with DT were tested with the Y-maze scale. Neurogenesis was studied with the immunohistochemical markers BrdU, PCNA, Dcx and NeuN. The results showed a significant decrease in learning ability and neurogenesis in the hippocampus simultaneously from the ninth day of treatment (D9) when the models showed loss of cholinergic neurons and reduction of hippocampal cells. Administration of thiamine in the diet reversed learning ability, as well as the decrease in hippocampal neurogenesis induced by DT in the early pathological pre-injury phase [25]. In a clinical study by Benton et al., (1995), involving one hundred and twenty young adult women with ingestion of $50 \mathrm{mg}$ thiamine, the treated group had a significant improvement in mood (after 2 months use) and in time reaction compared to the control group (placebo) [26]. Several authors have demonstrated effects and various concentrations of thiamine use, as shown in Table 1.

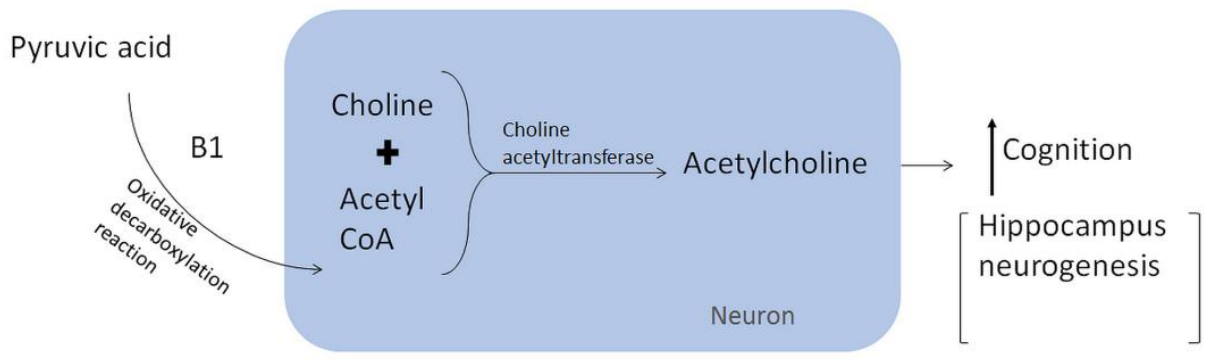

Fig. 1: Mechanism of Action of Thiamine.

Table 1: Clinical Studies of Thiamine Deficiency and Supplementation.

\begin{tabular}{|c|c|c|c|c|}
\hline Author & $\mathrm{n}$ & Dose (mg) & Time & Effect \\
\hline \multirow[b]{2}{*}{ Brožek et al. (1957) [27] } & 10 & Privation & 15-27 days & \multirow{2}{*}{$\begin{array}{l}\text { Anorexia, muscle weakness, irritability, depression. } \\
\text { Improvement of symptoms observed in the deprivation } \\
\text { of this vitamin. }\end{array}$} \\
\hline & & 5 & 9-21 days & \\
\hline Benton et al., (1995) [26] & 129 & 14 & 4 months & Improved mood in women. \\
\hline Smidt et al., (1991) [28] & 80 & 10 & 6 weeks & Increased sense of well-being and decrease fatigue. \\
\hline \multirow{2}{*}{$\begin{array}{l}\text { Heseker et al., (1990) } \\
\text { [29] }\end{array}$} & \multirow[t]{2}{*}{1081} & Privation & \multirow{2}{*}{2 months } & $\begin{array}{l}\text { Introversion, inactivity, fatigue, decreased confidence } \\
\text { and mood. }\end{array}$ \\
\hline & & 3 & & Increased sociability, sensitivity and mood. \\
\hline \multirow{3}{*}{ Harrell (1946) [30] } & 120 & 1 (boys) & \multirow{3}{*}{1 year } & Adequate amount of thiamine $=$ normal children. \\
\hline & & 0,9 (girls) & & \\
\hline & & 2 both sexes & & $\begin{array}{l}\text { Taller children, with better vision, faster reaction times } \\
\text { and better results on memory and intelligence tests. }\end{array}$ \\
\hline
\end{tabular}

\subsection{Pyridoxine and cobalamin}

Pyridoxine (B6) and cobalamin (B12) act in the CNS as a cofactor in the metabolism reactions of homocysteine [31]. Homocysteine $(\mathrm{HCl})$ is a sulfhydryl amino acid formed from the demethylation of methionine and is metabolized by two pathways: the remethylation (dependent on vitamin B12 and folic acid) and the transsulfuration (dependent on vitamin B6) [32]. The mechanisms of action cited below are summarized schematically in Figure 2.

Cobalamin (B12) passes through the blood-brain barrier bound to transcobalamin II protein (TC2) forming the cobalamin-TC2 complex, which crosses the barrier by endocytosis, using the high affinity cell surface receptor [33]. Pyridoxine (B6) is absorbed from the gastrointestinal tract and converted in the liver into pyridoxal 5'phosphate, the enzyme non-specific alkaline phosphatase.
In blood, the same enzyme removes phosphate, producing pyridoxal, which is then transported by the blood-brain barrier [34]. B6 is a cofactor in the synthesis of cysteine from Hci. Cysteine is a glutathione precursor, which is an antioxidant substance, and acts by inhibiting Hci oxidant action [2]. B6 and B12 also act as cofactors in the S-adenosyl-methionine synthesis (SAM), which is an enzymatic cofactor of glutathione production [35]. SAM is also a precursor in the synthesis of melatonina, produced in the pineal gland. Melatonin has an antioxidant role, as glutathione [36]. In fact, studies show that SAM synthesis can enhance cognitive performance [37]. It also adds the fact that B6 and SAM are essential cofactors in the pathway of synthesis of epinephrine, which is involved in learning processes and memory consolidation [38], [39].

Diets deficient in B6 and B12 induce in mice high levels of HCY in plasma and high levels of amyloid-beta, neurotoxicity indicative for leading to neuronal apoptosis caused by oxidative stress [40]. Added to this, in vitro experiments show that supplementa- 
tion with B6 and B12 can treat diseases related with dementia by reducing the amyloid-beta accumulation in the cortex and hippocampus [41]. It was concluded that high levels of homocysteine (HCY) in plasma are directly related to deficiency of vitamins B6 and B12 [2].

Other clinical studies evaluated the rate of brain atrophy in Alzheimer's patients who have low levels of $\mathrm{HCl}$, after treated with B6 (pyridoxine) and B12 (cobalamin). The results showed that the rate of atrophy and cognitive impairment declined in 85 patients treated, after 2 years [42]. In another study of these same authors carried out in 2012 included 133 patients with Alzheimer's disease who were treated with B6 and B12. In this evaluation, cognitive decline caused by the disease was retarded in the end of 2 years of treatment [43]. In another study, 211 young, adult and old women were tested with B6 and B12 supplementation to assess the association between cognition and vitamins $\mathrm{B}$. The processing speed and working memory were used as parameter. The result was positive, there was improvement in memory and learning of young women, after 35 days of treatment [44]. Furthermore, a clinical study of association between the high concentration of Hci in plasma and cognitive performance evaluated 87498 individuals presenting a associatin of 7-8\% of Hci levels with cognition [45].

Deficiency of some neurotransmitter precursors can also cause symptoms of attention deficit hyperactivity disorder in children, especially amino acid and vitamin B deficiency [46]. Therefore, supplementation with vitamins B6 and B12 provide improvement in cognition and learning, as they assist in the processes of synthesis of those neurotransmitters that are directly involved in cognitive processes of brain [47]. Table 2 outlines some clinical studies with different doses of supplementation of vitamins B6 and B12.

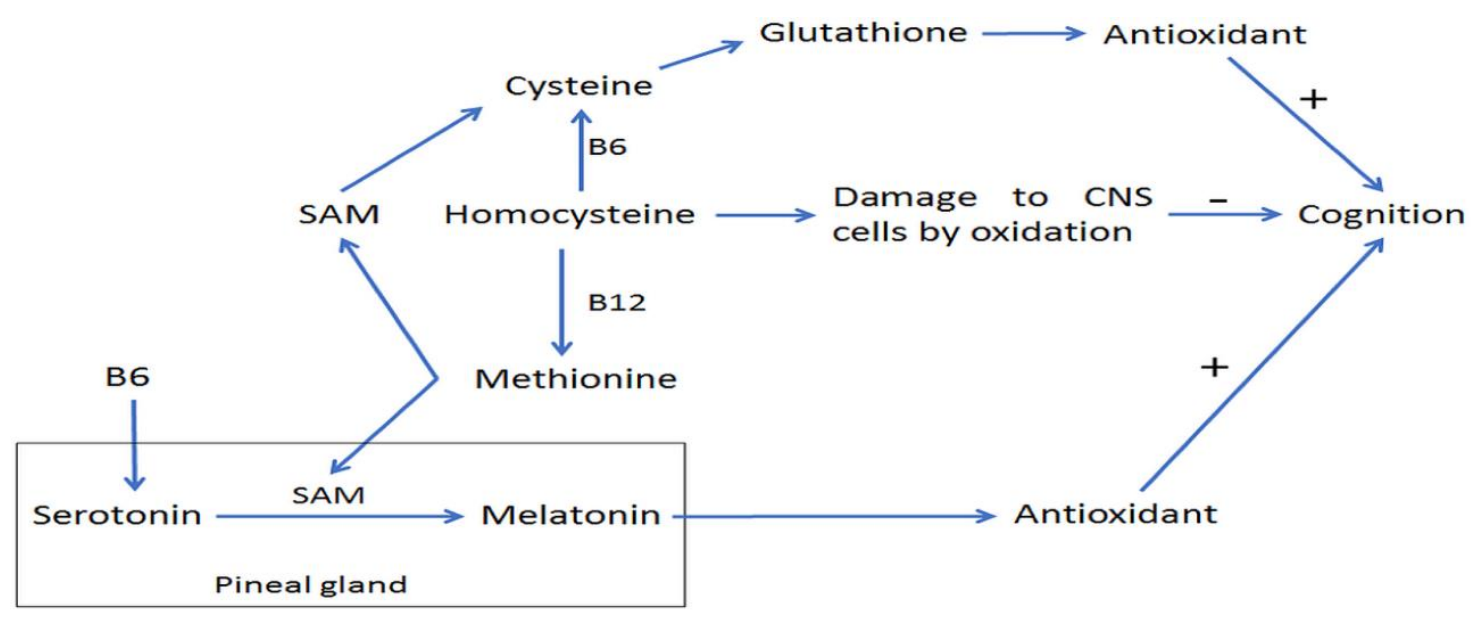

Fig. 2: Mechanism of Action of B6 and B12.

Table 2: Clinical Studies of B6 and B12 Vitamins.

\begin{tabular}{|c|c|c|c|c|c|}
\hline Author & B6 Vitamin & B12 Vitamin & Time & Patients & Results \\
\hline $\begin{array}{l}\text { Smith et al., } 2010 \\
\text { [42] }\end{array}$ & $20 \mathrm{mg}$ & $0,5 \mathrm{mg}$ & 24 months & 85 & $\begin{array}{l}\text { Brain atrophy rate and cognitive impair- } \\
\text { ment decreased }\end{array}$ \\
\hline $\begin{array}{l}\text { Jager et al., } 2012 \\
\text { [43] }\end{array}$ & $20 \mathrm{mg}$ & $0,5 \mathrm{mg}$ & 24 months & 133 & $\begin{array}{l}\text { It was slowed cognitive decline caused by } \\
\text { the disease }\end{array}$ \\
\hline $\begin{array}{l}\text { Bryan et al., } 2002 \\
\text { [44] }\end{array}$ & $75 \mathrm{mg}$ & $15 \mu \mathrm{g}$ & 35 days & 211 & $\begin{array}{l}\text { Supplementation with B vitamins shows } \\
\text { positive results on memory and learning }\end{array}$ \\
\hline
\end{tabular}

\section{Neurotransmitters aminoacids}

The central nervous system (CNS) shows high concentrations of certain aminoacids which bind to postsynaptic receptors, acting thus as inhibitory or excitatory neurotransmitters.

Inhibitory and excitatory neurotransmitters regulate diverse behavioral processes, including sleep, learning, memory and sensation of pain. They are also implicated in many pathological processes, such as epilepsy and neurotoxicity. The interactions between ion channels, receptors that regulate these channels and aminoacid neurotransmitters in the CNS are the molecular basis of these processes. This section will discuss the operation of the two major systems of aminoacid neurotransmission in the CNS, which involve the gamma-aminobutyric acid (GABA) and glutamate.

\subsection{Glutamate}

Excitatory aminoacids have been proposed as the main neurotransmitter of the central nervous system. Studies suggest that the excitatory aminoacids may play a role in learning and memory [48]. The binding of glutamate to its receptor triggers molecular and cellular events associated with numerous physiological and pathophysiological pathways, including the development of an increased sensation of pain (hyperalgesia), brain neurotoxicity or synaptic alterations involved in certain types of memory formation [49].
The glutamate synthesis proceeds via two distinct pathways. In one of these pathways, alpha-ketoglutarate formed in the citric acid cycle is transaminated to glutamate in the nerve endings in the CNS. Alternatively, the glutamine produced and secreted by the glial cells is transported in the nerve endings and converted into glutamate by glutaminase [49]. There are two isoforms, Dglutamate and L-glutamate.

L-Glutamate is the most abundant free amino acid in the brain and the predominant excitatory neurotransmitter in the CNS of vertebrates. Among its many functions, the L-glutamate plays a critical role in the synaptic plasticity and its maintenance [50]; also contributes to learning and memory through changes in the use of synaptic efficacy, such as maintenance of long-term potential [51]. In nerve terminals, L-glutamate is stored in vesicles and released by a mechanism dependent on calcium. Once in the synaptic cleft, L-glutamate binds to and activates postsynaptic glutamate receptors. Although many different subtypes of glutamate receptors have been identified [52] ionotropic receptors have been the most extensively studied. They are subdivided into three classes: the AMPA (alpha-amino-3-hydroxy-5-methyl-4-isoxazole propionic acid), kainate and NMDA (N-methyl D-aspartate) receptors, the NMDA being the most important. The functions of the NMDA receptors are as sodium and calcium transporter, having five separate binding sites, each of which is affected by different substrates susceptible to alter the receptor affinity. L-glutamate action is ended by removal of this substance from the synaptic cleft by 
neuronal and glial presynaptic uptake systems of high affinity, several of which have previously been cloned [53], [54], and [55]. The voltage dependent blockade of the NMDA receptor by $\mathrm{Mg} 2+$ and its high permeability to $\mathrm{Ca} 2+$ make inherently appropriate the indications for a role in mediating synaptic plasticity. The flow of ions through the channel operated by the NMDA receptor is normally only achieved in the presence of a strong local depolarization induced, e.g., by $\mathrm{Na} 2+$ influx due to activation of glutamate receptor AMPA type [56]. Thus, two simultaneous processes are required for physiological activation of NMDA receptor learning channel, allowing the translation of quantitative information [57]. The regulatory mechanisms of neuronal genes triggered by binding to the NMDA receptor become important to understand the mechanisms of learning, memory and other long-term adaptive changes in neurons. The neurotransmitter glutamate stimulates rapid and transient induction of several genes including the protooncogene c-fos [51] and the promoter Zif-268 [58]. The c-fos is the most commonly used markers for neuronal plasticity. While a study on the c-fos gene provides information about the neural plasticity, Zif-268 has been implicated in long-term memory consolidation process [58], [59]. The c-fos promoter contains several critical regulatory elements, including the serum response element (SRE) that mediate transcription induced by glutamate in neurons. Transcription factors of serum response factor (SRF) and Elk-1 can mediate transcription of SRE in cortical neurons by glutamate induction. There are at least two distinct pathways, through which glutamate signals act through the SRE: a path SRF-dependent, which can operate in the absence of elk; and an Elk-dependent pathway. The activation of the Elk transcription dependent pathway seems to require phosphorylation of Elk-1 by extracellular signal regulated kinases (ERKs), providing evidence for a physiological role of ERK in glutamate signaling in neurons. Taken together, these findings suggest that the SRF, Elk and ERK pathways may play an important role in neuroplasticity [51]. Figure 3 shows the summarized Mechanism of Action of L-glutamate at NMDA receptors.

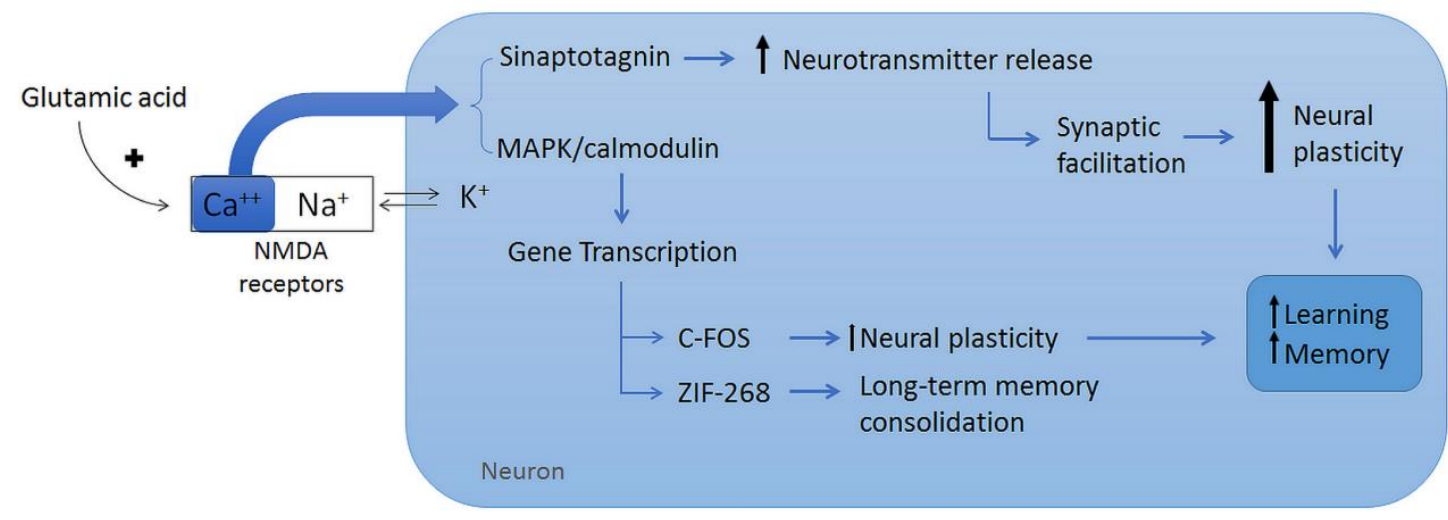

Fig. 3: Mechanism of Action of L-Glutamate.

The plasma concentrations of L-glutamate can fluctuate during the day as a result of changes in the diet, metabolism and protein turnover. If these changes were directly transferred to the interstitial space of the brain, they would have effects on neuronal synaptic communication [60].

Consequently, the passive flux of many polar solutes such as Lglutamate, is very limited. To compensate the limited passive exchange, the cells that make up the external layer of the bloodbrain barrier (BBB) contain different levels (20 or more) of specific transport systems, which regulate the solute flux from blood to the cerebrospinal fluid and brain interstitial fluid and again out [60].

The first transport systems to be proposed were identified based on the results of uptake studies in vivo [61], [62], [63]. Such carriers include X2 system, that acts independently of sodium, promoting absorption with high affinity to amino acid with anionic side chains, including L-glutamate and L-aspartate [60].

Although such an arrangement helps to protect the greater part of the brain from the plasma changes of circulating L-glutamate, there are some brain areas that contain no BBB, allowing rapid uptake of L-glutamate from the circulation [64]. These are collectively known as circumventricular organs and include the median eminence, area postrema, subfornical organ, organ subcomissural, pineal gland, pituitary and organum vasculosum of the terminal blade [65]. Uptake rates in the brain to small solutes in these areas are greater than the BBB by 10 to 1000 times [64], [65], [66], [67]. Once inside the brain extracellular fluid, solutes can move into adjacent brain areas via intercellular diffusion or by flow along the Virchow-Robin spaces. Such movement has been documented for glutamate and aspartate in animals after high-dose administration amino acids [68], [69]. The result is that certain areas of the brain are vulnerable to fluctuations in the acute glutamate concentration in plasma of great magnitude as a result of "flooding" from the circumventricular organs [60].
There are recent hypotheses that suggest a critical role of glutamate receptors in memory potentiation and retention in the hippocampus, in long term. Flood et al (1990) trained rats to avoid shock [48]. After the formation of learning they injected intracerebroventricularly agonists and antagonists of various classes of glutamate receptors. The retention test (specific memory acquisition) was assessed one week after training. NMDA receptor agonists have been able to improve memory retention in a dosedependent manner. L-glutamate, but not D-glutamate, increased memory retention. Administration of antagonists $24 \mathrm{~h}$ after training did not impair memory retention [48]. Vogel et al. (1966) reviewed a large number of clinical studies in which glutamic acid was administered in healthy subjects and individuals with mental retardation, who underwent tests [70]. The authors concluded that glutamic acid reduces the severity of mental retardation, resulting in better performance in intelligence tests in both subject populations.

\subsection{GABA}

From the two major classes of neuroactive aminoacids, $\gamma$ aminobutyric acid (GABA) is the major inhibitory [49], [71]. It is known that GABA plays a fundamental role in encoding information and behavioral control [72], in the regulation of motor function [73], [74], [75] and in motor learning [76], [77]. Further important, GABA appears to be also involved in action selection processes [78] and inhibition of responses that occur in fronto striatal circuits [79] and are likely to play key role in neuromodulation of action control processes [78], [80], [81].

GABAergic neurons play an important role in the control mechanisms in various centers of the stem and hypothalamus. If its activity within these structures is compromised, abnormally increased responses can be observed, for example: emotional reactivity, cardiac and respiratory functions, food and water intake functions, 
sweating, insulin secretion, gastric acid release and colonic motility [82].

GABA synthesis is mediated by glutamic acid decarboxylase (GAD), which catalyzes the decarboxylation of glutamate to GABA, in the GABAergic nerve endings [83] (Fig. 4). Therefore, the amount of GABA in the brain tissue correlates with the amount of functional GAD, which requires pyridoxal phosphate (Vitamin B6) as a cofactor. In response to an action potential GABA release occurs into the synaptic cleft by fusion of vesicles containing GABA in the presynaptic membrane [49], [84], [85], [86].
The end of the GABA action in the synapse depends on removal of the extracellular space. Neurons and glial cells take GABA by specific GABA transporters (GAT). Inside the cells, the widely distributed mitochondrial enzyme GABA-transaminase (GABA$\mathrm{T}$ ), catalyzes the conversion of GABA to succinic semialdehyde (SSA), which is subsequently oxidized to succinic acid by the SSA dehydrogenase (SSADH), entering hereafter in the Krebs cycle, which is transformed into $\alpha$-ketoglutarate. Thereupon, GABA-T regenerates glutamate from $\alpha$-ketoglutarate [49], [84], [85], [86] (Fig. 4).

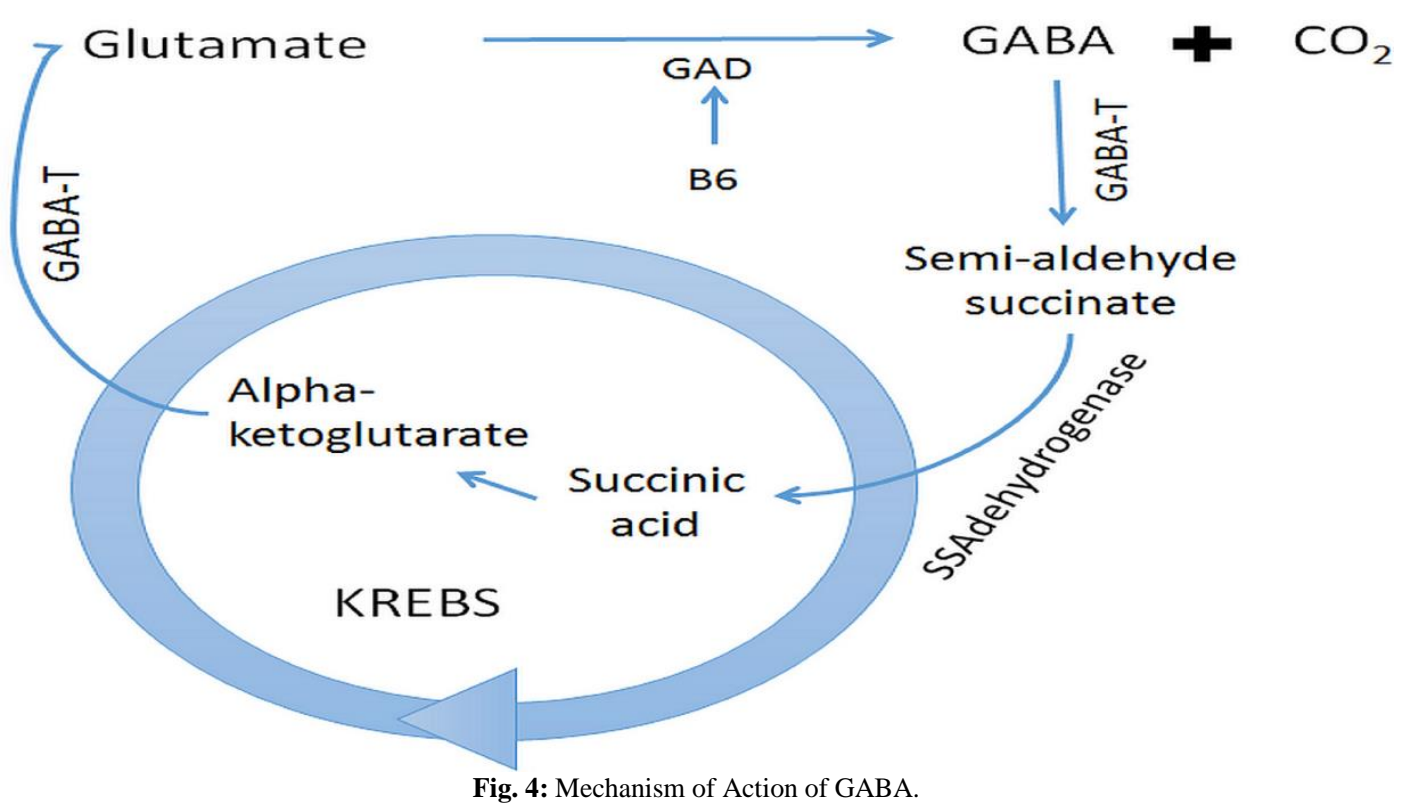

The CNS cell membranes of most neurons and astrocytes of vertebrates expresses GABA receptors and, because of this, these receptors influence in several functions and neural circuits [87, 88]. There are two types of GABA receptors. The ionotropic GABA receptors $\left(\mathrm{GABA}_{\mathrm{A}}\right.$ and $\mathrm{GABAC}$ ) consist of membrane proteins of multiple subunits, which bind to GABA, opening an intrinsic chloride ion channel [89]. The metabotropic GABA receptors (GAB$\left.A_{B}\right)$ are heterodimeric receptors coupled to G-protein that affect neuronal ionic currents via second messengers [49], [90], [91]. The most abundant GABA receptors in the CNS consist of the ionotropic $\mathrm{GABA}_{\mathrm{A}}[90]$.

The inhibitory postsynaptic current (IPSC) consists of quick responses triggered by very short bursts (high frequency) of GABA release in the synapse. The prolonged occupation of the agonist's sites by GABA also leads to a desensitization of the GABAA receptor, a transition to an inactive state on the agonist [91]. The selective activation of chloride channels (crescent conductance) deviates neuronal transmembrane voltage to the equilibrium potential of the $\mathrm{Cl}(-70 \mathrm{mV})$ [92]. This flow hyperpolarizes $\mathrm{Cl}$ or stabilizes the postsynaptic cell close to its membrane potential in normal resting $(\mathrm{Vm} \sim 65 \mathrm{mV})$, thereby reducing the likelihood that excitatory stimuli can initiate action potentials. The open $\mathrm{Cl}$ channels attenuate the change in membrane potential produced by excitatory synaptic currents, a so-called shunting effect. This process provides a molecular explanation for the inhibitory effects of GABA signaling through $\mathrm{GABA}_{\mathrm{A}}$ receptors. [49], [93].

In the literature there are conflicting results about the GABA entry into the brain across the blood brain barrier (BBB). The BBB is a tightly sealed layer of brain endothelial cells that form solid joints and prevent the majority of solutes between the brain based on the size, charge and lipid solubility. However, as pointed out by Shyamaladevi and colleagues (2002), recent studies have shown that $\mathrm{BBB}$ is much more dynamic than was predicted in the past and some solutes passages may occur by transcytosis, transport mediated by carrier, or simple diffusion of hydrophobic substanc- es [94]. Although there is some evidence for only a limited GABA brain penetration [95], [96], a more recent study using rats has shown that GABA administration alone increased GABA concentration in brain, when compared with untreated mice [97].

Still on its effects, GABA has also been linked to the effectiveness of cascade action processes. Consistent with this hypothesis, Yildiz et al (2014) have shown by magnetic resonance spectroscopy (MRS) that superior performance of cascade action was associated with increased striatal GABA concentrations [98]. Another point, the active transcutaneous stimulation of the vagus nerve (tVNS) which increases the concentration of GABA and norepinephrine (NE), improved functions of response selection during the cascade action, compared with the stimulus simulation [99]. These results suggest a critical role of GABA in the neuromodulation of cascade action processes. They also suggest that the increase $[98,99]$ not too high [100] of GABA levels are associated with better performance of these cascade actions.

In another study, Steenbergen et al (2015b) aimed to provide converged and direct evidence about the possible key role of the GABAergic system in modulating the efficacy of cascade action [101]. To this end, the subject received a dose of $800 \mathrm{mg}$ of synthetic GABA [97], [102] or $800 \mathrm{mg}$ of microcrystalline cellulose (placebo). The results suggest that systemic administration of synthetic GABA directly influences the effectiveness of the cascade action as measured by a change stop test - a well established diagnostic index (Verbruggen et al, 2008). GABA appears to modulate the performance as much as a more parallel strategy of overlap (i.e., when the interruption of a current task and a change of alternative response were required simultaneously) and as a strategy more in series step-by-step is requested (ie when switching to the alternative response was required after the process stop now was over) [103].

Other studies have shown that psychological stress affect the secretion of salivary cortisol in response to the anticipation of negative events, such as academic tests [104, 105, 106, 107]. The 
chromogranin $\mathrm{A}(\mathrm{CgA})$ and salivary cortisol are known stress markers in humans [108], CgA being ubiquitously secreted in several tissue types, including, as recently discovered, in the submandibular glands [109], [110]. Kanehira et al (2011) observed that salivary secretion levels of chromogranin A were significantly lower in subjects who did intake 25 and / or $50 \mathrm{mg}$ of GABA in comparison with the control group [111].

Other studies also report the GABA effect on relaxation and stress reduction. Abdou et al (2006) found that oral administration of GABA increased significantly alpha waves and decreased beta waves in the brain, and has maintained the levels of immunoglobulin A in saliva, when the subjects were subjected to stress conditions, such as crossing a suspension bridge [112]. This study showed that GABA could induce relaxation by decreasing anxiety while increasing immunity under stress conditions.

Kanehira et al (2011) determined in a study the effects of a drink containing GABA (control group $=0 \mathrm{mg}$, group $1=25 \mathrm{mg}$, group $2=50 \mathrm{mg}$ of GABA) in feelings of individuals with chronic fatigue after the performance of a task [111]. Changes in mood measured by the Visual Analogue Scale and the Mood Profile (VAS and POMS) were significantly different in GABA 50mg group and the other two groups. Regarding the cortisol levels and $\mathrm{CgA}$ in saliva, an arithmetic task was made to induce mental stress. Samples of saliva control group showed a significant increase in $\mathrm{CgA}$ levels, while the group of $25 \mathrm{mg}$ GABA showed a significantly lower level of $\mathrm{CgA}$. This trend was more pronounced in the 50mg GABA group. The results of cortisol were similar. In addition, the number of correct responses on tasks was significantly higher in the 50mg GABA group, whereas there was no marked difference in the comparison between the control group and the group 25mg GABA [111].

Recent evidence also suggests that a deficit in behavioral inhibition, common in patients with ADHD may be linked to a deficit in cortical inhibition of the GABAergic pathway. Experimental studies have shown that knockout mice for subtype 1 of GABA transporter (GAT1) gain hyperactive profiles and display an impaired memory, as well as low levels of concentration and attention with increased impulsivity [113].

Edden and coworkers (2012) compared two groups of children, one of healthy individuals and one of individuals with ADHD, using magnetic resonance spectroscopy (MRS) for measuring the volume of GABA concentration in the primary somatosensory and motor cortex. MRS showed that concentration of GABA in children with ADHD is reduced when compared with children with normal development, suggesting that there is a deficiency in GABA pathway [114]. These studies are summarized in Table 3 .

Table 3: Clinical Studies of GABA

\begin{tabular}{|c|c|c|c|}
\hline Autor & Patients & Dose $(\mathrm{mg})$ & Effects \\
\hline $\begin{array}{l}\text { Steenbergen } \\
\text { et al., } 2015\end{array}$ & 30 & $800 \mathrm{mg}$ & $\begin{array}{l}\text { Modulation of the efficacy of } \\
\text { the cascade action. }\end{array}$ \\
\hline $\begin{array}{l}\text { Abdou et } \\
\text { al., 2006 } \\
{[112]}\end{array}$ & 13 & $100 \mathrm{mg}$ & $\begin{array}{l}\text { Increased alpha waves and } \\
\text { decreased beta waves. De- } \\
\text { creased anxiety, induction of } \\
\text { relaxation. } \\
\text { Increased immunity in stress } \\
\text { situations. }\end{array}$ \\
\hline $\begin{array}{l}\text { Kanehira et } \\
\text { al., } 2011 \\
{[111]}\end{array}$ & 30 & $25 \mathrm{mg}$ & $\begin{array}{l}\text { Good performance in stress } \\
\text { induction tests, decrease of } \\
\text { physical fatigue. } \\
\text { More precise performance in } \\
\text { stress induction tests, as well as } \\
\text { reduction of physical and psy- } \\
\text { chological fatigue. }\end{array}$ \\
\hline
\end{tabular}

\section{Conclusion}

Because of their metabolic interdependence, the B complex vitamins have to be regarded as a functional unit whose individual members act like links in a chain of biochemical reactions. Four major mechanisms can be identified by which micronutrients in- fluence cognitive function: through their role in neurotransmitter synthesis; by neuronal membrane and receptor modification; by influencing brain energy requirements; and via their role in Hcy metabolism.

Inhibitory and excitatory neurotransmitters regulate diverse behavioral processes, including sleep, learning, memory and sensation of pain. They are also implicated in many pathological processes, such as epilepsy and neurotoxicity. Clinical evidence shows that all B vitamins have a fundamental role in neurotransmitters, lipids and proteins metabolism, and act differently in various enzyme systems, participating as co-enzymes in the activation of numerous metabolic processes

\section{References}

[1] M.N. García-Casal, C. Osorio, M. Landaeta, I. Leets, P. Matus, F Fazzino, E. Marcos. High prevalence of folic acid and vitamin B12 deficiencies in infants, children, adolescents and pregnant women in Venezuela. Eur J Clin Nutr, v. 59, n. 9, p. 1064-70, Sep 2005 ISSN 0954-3007 (Print) 0954-3007.

[2] R. Obeid; W. Herrmann. Mechanisms of homocysteine neurotoxicity in neurodegenerative diseases with special reference to dementia. FEBS Lett, v. 580, n. 13, p. 2994-3005, May 29 2006. ISSN 0014 5793 (Print) 0014-5793.

[3] P. Verhoef, M.J. Stampfer, J.F. Buring, J.M. Gaziano, R.H. Allen, S.P. Stabler, et al. Homocysteine metabolism and risk of myocardial infarction: relation with vitamins B6, B12, and folate. Am J Epidemiol, v. 143, n. 9, p. 845-59, May 1 1996. ISSN 0002-9262 (Print) 0002-9262.

[4] J. Selhub, L.C. Bagley, J. Miller, I.H. Rosenberg. B vitamins, homocysteine, and neurocognitive function in the elderly. Am J Clin Nutr, v. 71, n. 2, p. 614s-620s, Feb 2000. ISSN 0002-9165 (Print) $0002-9165$

[5] M.J. Medrano, M.J. Sierra, M.T. Olalla, G. López-Abente. The association of dietary folate, B6, and B12 with cardiovascular mortality in Spain: an ecological analysis. Am J Public Health, v. 90, n. 10 , p. 1636-8, Oct 2000. ISSN 0090-0036 (Print) 0090-0036.

[6] J.L. Simpson. L.B. Beiley, K. Pietrzik, B. Shane, W. Holzgreve. Micronutrients and women of reproductive potential: required dietary intake and consequences of dietary deficiency or excess. Part I-Folate, Vitamin B12, Vitamin B6. J Matern Fetal Neonatal Med, v. 23, n. 12, p. 1323-43, Dec 2010. ISSN 1476-4954.

[7] L. Bettendorff, F. Mastrogiacomo, S.J. Kish, T. Grisar. Thiamine, Thiamine Phosphates, and Their Metabolizing Enzymes in Human Brain. J Neurochem, 1996. ISSN 1.

[8] R.H. Haas. Thiamin and the brain. Annu Rev Nutr, v. 8, p. 483-515, 1988. ISSN 0199-9885 (Print) 0199-9885.

[9] C.G. Harper, M. Giles, R. Finlay-Jones. Clinical signs in the Wernicke-Korsakoff complex: a retrospective analysis of 131 cases diagnosed at necropsy. J Neurol Neurosurg Psychiatry, v. 49, n. 4, p. 341-5, Apr 1986. ISSN 0022-3050 (Print) 0022-3050.

[10] S.R. Pitkin; L.M. Savage. Age-related vulnerability to diencephalic amnesia produced by thiamine deficiency: the role of time of insult. Behav Brain Res, v. 148, n. 1-2, p. 93-105, Jan 5 2004. ISSN 01664328 (Print) 0166-4328.

[11] M.H. Donovan, U. Yazdani, R.D. Norris, D. Games, D.C. German, A.J. Eisch. Decreased adult hippocampal neurogenesis in the PDAPP mouse model of Alzheimer's disease. J Comp Neurol, v. 495, n. 1, p. 70-83, Mar 1 2006. ISSN 0021-9967 (Print) 0021-9967.

[12] M. Gold, R.A. Hauser, M.F. Chen. Plasma thiamine deficiency associated with Alzheimer's disease but not Parkinson's disease. Metab Brain Dis, v. 13, n. 1, p. 43-53, Mar 1998. ISSN 0885-7490 (Print) 0885-7490.

[13] T.M. Jeitner, H. Xu, G.E. Gibson. Inhibition of the alphaketoglutarate dehydrogenase complex by the myeloperoxidase products, hypochlorous acid and mono-N-chloramine. J Neurochem v. 92, n. 2, p. 302-10, Jan 2005. ISSN 0022-3042 (Print) 0022-3042.

[14] N.Y. Calingasan, S.E. Gandy, H. Barker, K.F. Sheu, J.D. Smith, B.T. Lamb, et al. Novel neuritic clusters with accumulations of amyloid precursor protein and amyloid precursor-like protein $2 \mathrm{immu}$ noreactivity in brain regions damaged by thiamine deficiency. Am J Pathol, v. 149, n. 3, p. 1063-71, Sep 1996? ISSN 0002-9440 (Print) 0002-9440

[15] E. Drapeau, W. Mayo, C. Aurousseau, M.L. Moal, P.V. Piazza, D.N. Abrours. Spatial memory performances of aged rats in the water maze predict levels of hippocampal neurogenesis. PNAS, v. 100 , n. 24, 2003. ISSN 24 
[16] S.A. Goldman; F. Nottebohm. Neuronal production, migration, and differentiation in a vocal control nucleus of the adult female canary brain. Proc Natl Acad Sci U S A, v. 80, n. 8, p. 2390-4, Apr 1983. ISSN 0027-8424 (Print)

[17] H. Van Praag, B.R. Christie, T.J. Sejnowski, F.H. Gage. Running enhances neurogenesis, learning, and long-term potentiation in mice. In: (Ed.). Proc Natl Acad Sci U S A, v.96, 1999. p.13427-31. ISBN 0027-8424 (Print) 1091-6490 (Electronic). https://doi.org/10.1073/pnas.96.23.13427.

[18] S. Becker. A computational principle for hippocampal learning and neurogenesis. Hippocampus, v. 15, n. 6, p. 722-738, 2005. https://doi.org/10.1002/hipo.20095.

[19] M. Carlén, R.M. Cassidy, H. Brismar, G.A. Smith, L.W. Enquist, J. Frisén. Functional integration of adult-born neurons. Current Biology, v. 12, n. 7, p. 606-608, 2002. https://doi.org/10.1016/S09609822(02)00771-6.

[20] N.B. Hastings; E. Gould. Rapid extension of axons into the CA3 region by adult-generated granule cells. Journal of Comparative $\begin{array}{lllll}\text { Neurology, } & \text { v. } & 413, & \text { p. } & 146-154,\end{array}$ https://doi.org/10.1002/(SICI)10969861(19991011)413:1<146::AID-CNE10>3.0.CO;2-B

[21] E.A. Markakis; F.H. Gage. Adult-generated neurons in the dentate gyrus send axonal projections to field CA3 and are surrounded by synaptic vesicles. Journal of comparative neurology, v. 406, n. 4, p. 449-460, $1999 . \quad$ https://doi.org/10.1002/(SICI)10969861(19990419)406:4<449::AID-CNE3>3.0.CO;2-I

[22] H.A.Cameron, C.S. Woolley, B.S. McEwen, E. Gould. Differentiation of newly born neurons and glia in the dentate gyrus of the adult rat. Neuroscience, v. 56, n. 2, p. 337-44, Sep 1993. ISSN 03064522 (Print) 0306-4522.

[23] H.G. Kuhn, H. Dickinson-Anson, F.H. Gage. Neurogenesis in the dentate gyrus of the adult rat: age-related decrease of neuronal progenitor proliferation. J Neurosci, v. 16, n. 6, p. 2027-33, Mar 15 1996. ISSN 0270-6474 (Print) 0270-6474

[24] H. Van Praag, A.F. Schinder, B.R. Christie, N. Toni, T.D. Palmer, F.H. Gage. Functional neurogenesis in the adult hippocampus. Nature, v. 415, n. 6875, p. 1030-1034, 2002 https://doi.org/10.1038/4151030a.

[25] N. Zhao, C. Zhong, Y. Wang, Y. Zhao, N. Gong, G. Zhou, T. Xu, Z. Hong. Impaired hippocampal neurogenesis is involved in cognitive dysfunction induced by thiamine deficiency at early prepathological lesion stage. Neurobiology of disease, v. 29, n. 2, p. 176-185, 2008. https://doi.org/10.1016/i.nbd.2007.08.014

[26] D. Benton, J. Haller, J. Fordy. Vitamin supplementation for 1 year improves mood. Neuropsychobiology, v. 32, n. 2, p. 98-105, 1995 https://doi.org/10.1159/000119220.

[27] J. Brožek, H. Guetzkow. Psychologic effects of thiamine restriction and deprivation in normal young men. The American journal of clinical nutrition, v. 5, n. 2, p. 109-120, 1957.

[28] L.J. Smidt, F.M. Cremin, L.E. Grivetti, A.J. Clifford. Influence of thiamin supplementation on the health and general well-being of an elderly Irish population with marginal thiamin deficiency. Journal of gerontology, v. 46, n. 1, p. M16-M22, 1991 https://doi.org/10.1093/geronj/46.1.M16.

[29] H. Heseker, W. Kiibler, J. Westenhssfer, V. Pudel. Psychische Verfinderungen als Friihzeichen einer suboptimalen Vitaminversorgung. Erniihrungs Umschau 1990, 37:87-94.

[30] R.F. Harrell. Mental response to added thiamine. Journal of Nutrition, v. 31, n. 3, p. 283-98, 1946.

[31] R. Clarke, A.D. Smith, K.A. Jobst. Folate, vitamin B12, and serum total homocysteine levels in confirmed Alzheimer disease. Archives of neurology, v. 55, n. 11, p. 1449-1455, 1998. https://doi.org/10.1001/archneur.55.11.1449.

[32] R. R. McLean; M.T. Hannan. B vitamins, homocysteine, and bone disease: epidemiology and pathophysiology. Current osteoporosis reports, v. 5, n. 3, p. 112-119, 2007. https://doi.org/10.1007/s11914 007-0026-9

[33] D.G. Weir; J.M. Scott. Brain function in the elderly: role of vitamin B12 and folate. Br Med Bull, v. 55, n. 3, p. 669-82, 1999. ISSN 0007-1420 (Print) 0007-1420.

[34] M.D. Thompson, A. Killoran, M.E. Percy, M. Nezarati, D.E.C Cole, P.A. Hwang. Hyperphosphatasia with neurologic deficit: a pyridoxine-responsive seizure disorder? Pediatr Neurol, v. 34, n. 4, p. 303-7, Apr 2006. ISSN 0887-8994 (Print) 0887-8994.

[35] I.I. Kruman, C. Culmsee, S.L. Chan, Y. Kruman, Z. Guo, L.R. Penix, M.P. Mattson. Homocysteine elicits a DNA damage response in neurons that promotes apoptosis and hypersensitivity to excitotoxicity. J Neurosci, v. 20, n. 18, p. 6920-6, Sep 15 2000. ISSN 0270-6474 (Print) 0270-6474.
[36] R.J. Reiter, D.X. Tan, M.A. Pappolla. Melatonin relieves the neural oxidative burden that contributes to dementias. Ann N Y Acad Sci, v. 1035, p. 179-96, Dec 2004. ISSN 0077-8923 (Print) 0077-8923.

[37] D. Fontanari, C.D. Palma, G. Gioretti, F. Violante, M. Voltolina. Effects of S-adenosyl-L-methionine on cognitive and vigilance functions in the elderly. Current Therapeutic Research, v. 55, n. 6 , 1994. ISSN 6.

[38] P.E. Gold. Role of glucose in regulating the brain and cognition. Am J Clin Nutr, v. 61, n. 4 Suppl, p. 987s-995s, Apr 1995. ISSN 0002-9165 (Print) 0002-9165.

[39] L. Cahill; M.T. Alkire. Epinephrine enhancement of human memory consolidation: interaction with arousal at encoding. Neurobiol Learn Mem, v. 79, n. 2, p. 194-8, Mar 2003a. ISSN 1074 7427 (Print) 1074-7427.

[40] J.M. Zhuo; D. Pratico. Acceleration of brain amyloidosis in an Alzheimer's disease mouse model by a folate, vitamin B6 and B12deficient diet. Exp Gerontol, v. 45, n. 3, p. 195-201, Mar 2010. ISSN 0531-5565

[41] S. Scarpa, A. Fuso, F. D’Anselmi, R. A. Cavallaro. Presenilin 1 gene silencing by S-adenosylmethionine: a treatment for Alzheimer disease? FEBS Lett, v. 541, n. 1-3, p. 145-8, Apr 24 2003. ISSN 0014-5793 (Print) 0014-5793.

[42] A.D. Smith, S.M. Smith, C.A. Jager, P. Whitbread, C. Johnston, G. Agacinski, et al. Homocysteine-lowering by B vitamins slows the rate of accelerated brain atrophy in mild cognitive impairment: a randomized controlled trial. PLoS One, v. 5, n. 9, p. e12244, 2010. ISSN 1932-6203.

[43] C.A. Jager, A. Oulhaj, R. Jacoby, H. Refsum, A. D. Smith. Cognitive and clinical outcomes of homocysteine-lowering B-vitamin treatment in mild cognitive impairment: a randomized controlled trial. International journal of geriatric psychiatry, v. 27, n. 6, p. 592 600, 2012. https://doi.org/10.1002/gps. 2758 .

[44] J. Bryan, E. Calvaresi, D. Hughes. Short-term folate, vitamin B-12 or vitamin B-6 supplementation slightly affects memory performance but not mood in women of various ages. J Nutr, v. 132, n. 6 , p. 1345-56, Jun 2002. ISSN 0022-3166 (Print) 0022-3166.

[45] S.J. Duthie, L.J. Whalley, A.R. Collins, S. Leaper, K. Berger, I.J. Deary. Homocysteine, $\mathrm{B}$ vitamin status, and cognitive function in the elderly. Am J Clin Nutr, v. 75, n. 5, p. 908-13, May 2002. ISSN 0002-9165 (Print) 0002-9165

[46] K.L. Harding, R.D. Judah, C.E. Gant. Outcome-based comparison of Ritalin versus food-supplement treated children with AD/HD. Altern Med Rev, v. 8, n. 3, p. 319-30, Aug 2003. ISSN 1089-5159 (Print) 1089-5159

[47] J. Pellow, E.M. Solomon, C.N. Barnard. Complementary and alternative medical therapies for children with attentiondeficit/hyperactivity disorder (ADHD). Altern Med Rev, v. 16, n. 4 p. 323-37, Dec 2011. ISSN 1089-5159 (Print) 1089-5159.

[48] J.F. Flood, M.L. Baker, J.L. Davis. Modulation of memory processing by glutamic acid receptor agonists and antagonists. Brain Research, v. 521, 1990. ISSN 1-2.

[49] D.E. Golan. Farmacologia da Neurotransmissão GABAérgica e Glutamatérgica. In: (Ed.). Princípios de Farmacologia: A Base Fisiopatológica da Farmacoterapia. 2: EDITORA Guanabara Koogan S.A., 2009. Cap. 11, p.914. ISBN ISBN13: 9788527715201

[50] J.W. McDonald; M.V. Johnston. Physiological and pathophysiological roles of excitatory amino acids during central nervous system development. Brain Res Brain Res Rev, v. 15, n. 1, p. 41-70, JanApr 1990. https://doi.org/10.1016/0165-0173(90)90011-C

[51] Z. Xia, H. Dudek, C.K. Miranti, M.E. Greenberg. Calcium influx via the NMDA receptor induces immediate early gene transcription by a MAP kinase/ERK-dependent mechanism. J Neurosci, v. 16, n. 17, p. 5425-36, Sep 1 1996. ISSN 0270-6474 (Print) 0270-6474.

[52] S. Nakanishi. Molecular diversity of glutamate receptors and implications for brain function. Science, v. 258, n. 5082, p. 597-603, Oct 23 1992. ISSN 0036-8075 (Print) 0036-8075.

[53] M. Castagna, C. Shayakul, D. Trotti, V.F. Sacchi, W.R. Harvery, M.A. Hediger. Molecular characteristics of mammalian and insect amino acid transporters: implications for amino acid homeostasis. J Exp Biol, v. 200, n. Pt 2, p. 269-86, Jan 1997. ISSN 0022-0949 (Print) 0022-0949.

[54] Y. Kanai et al. A new family of neurotransmitter transporters: the high-affinity glutamate transporters. Faseb j, v. 7, n. 15, p. 1450-9, Dec 1994. ISSN 0892-6638 (Print) 0892-6638.

[55] Y. Kanai, C.P. Smith, M.A. Hediger. Family of neutral and acidic amino acid transporters: molecular biology, physiology and medica implications. Curr Opin Cell Biol, v. 9, n. 4, p. 565-72, Aug 1997. ISSN 0955-0674 (Print) 0955-0674. 
[56] G.L. Collingridge; W. Singer. Excitatory amino acid receptors and synaptic plasticity. Trends in pharmacological sciences, v. 11, n. 7, p. 290-296, 1990. https://doi.org/10.1016/0165-6147(90)90011-V.

[57] C.W. Cotman; D.T. Monaghan. Excitatory amino acid neurotransmission: NMDA receptors and Hebb-type synaptic plasticity.Annual review of neuroscience, v. 11, n. 1, p. 61-80, 1988. https://doi.org/10.1146/annurev.ne.11.030188.000425.

[58] F.F. Barbosa, J.R. Santos, Y.S.R. Meurer, P.T. Macedo, L.M.S Ferreira, I.M.O. Pontes, et al. Differential Cortical c-Fos and Zif268 Expression after Object and Spatial Memory Processing in a Standard or Episodic-Like Object Recognition Task. Front Behav Neurosci, v. 7, 2013.

[59] B. Bozon, S. Davis, S.Laroche. Regulated transcription of the immediate-early gene Zif268: mechanisms and gene dosagedependent function in synaptic plasticity and memory formation. Hippocampus, v. 12, n. 5, p. 570-7, 2002. ISSN 1050-9631 (Print) 1050-9631.

[60] Q.R. Smith. Transport of glutamate and other amino acids at the blood-brain barrier. J Nutr, v. 130, n. 4S Suppl, p. 1016s-22s, Apr 2000. ISSN 0022-3166 (Print) 0022-3166.

[61] W.H. Oldendorf. Brain uptake of radiolabeled amino acids, amines, and hexoses after arterial injection. Am J Physiol, v. 221, n. 6, p. 1629-39, Dec 1971. ISSN 0002-9513 (Print) 0002-9513.

[62] W.H. Oldendorf; J. Szabo. Amino acid assignment to one of three blood-brain barrier amino acid carriers. Am J Physiol, v. 230, n. 1, p. 94-8, Jan 1976. ISSN 0002-9513 (Print) 0002-9513.

[63] W.M. Pardridge. Regulation of Amino Acid Availability to Brain Selective Control Mechanisms For Glutamate. In: (Ed.). Glutamic Acid: Advances in Biochemistry and Physiology. New York: Raven Press, 1979. p.14.

[64] R.A. Hawkins, M.R. DeJoseph, P.A. Hawkins. Regional brain glutamate transport in rats at normal and raised concentrations of circulating glutamate. Cell Tissue Res, v. 281, n. 2, p. 207-14, Aug 1995. ISSN 0302-766X (Print) 0302-766x.

[65] P.M. Gross, R.G. Blasberg, J.D. Fenstemacher, C.S. Patlak. The microcirculation of rat circumventricular organs and pituitary gland Brain Res Bull, v. 18, n. 1, p. 73-85, Jan 1987. ISSN 0361-9230 (Print) 0361-9230.

[66] P.M. Gross. Morphology and physiology of capillary systems in subregions of the subfornical organ and area postrema. Can J Physiol Pharmacol, v. 69, n. 7, p. 1010-25, Jul 1991. ISSN 0008-4212 (Print) 0008-4212.

[67] S.W. Shaver, J.J. Pang, D.S. Wainman, K.M. Wall, P.M. Gross Morphology and function of capillary networks in subregions of the rat tuber cinereum. Cell Tissue Res, v. 267, n. 3, p. 437-48, Mar 1992. ISSN 0302-766X (Print) 0302-766x.

[68] M.T. Price et al. Uptake of exogenous glutamate and aspartate by circumventricular organs but not other regions of brain. J Neurochem, v. 36, n. 5, p. 1774-80, May 1981. ISSN 0022-3042 (Print) 0022-3042.

[69] M.T. Price, J.W. Olney, O.H. Lowry, S. Buchsbaum. Uptake of exogenous aspartate into circumventricular organs but not other regions of adult mouse brain. Journal of neurochemistry, v. 42, n. 3, p 740-744, 1984. https://doi.org/10.1111/j.1471-4159.1984.tb02745.x.

[70] W. Vogel, D.M. Broverman, J.G. Draguns, E.L. Klaiber. The role of glutamic acid in cognitive behaviors.Psychological bulletin, v. 65, n. 6, p. 367, 1966. https://doi.org/10.1037/h0023351.

[71] E. Roberts; S. Frankel. $\gamma$-aminobutyric acid in brain: its formation from glutamic acid. Journal of Biological Chemistry, v. 187, p. 5563, 1950.

[72] A. Adler, I. Finkes, S. Katabi, Y. Prut, H. Bergman. Encoding by synchronization in the primate striatum. J. Neurosci. 33, 4854-4866 (2013) https://doi.org/10.1523/JNEUROSCI.4791-12.2013.

[73] T.N. Chase; C.A. Tamminga. GABA system participation in human motor, cognitive, and endocrine function. In: (Ed.). GABAneurotransmitters: Munksgaard Copenhagen, 1979. p.283-294.

[74] B.E. Will, G. Toniolo, S. Brailowsky. Unilateral infusion of GABA and saline into the nucleus basalis of rats: 1. Effects on motor function and brain morphology. Behavioural brain research, v. 27, n. 2 , p. 123-129, 1988. https://doi.org/10.1016/0166-4328(88)90038-1.

[75] F. Boy, J. Evans, R.A.E. Edden, K.D. Singh, M. Husain, P. Summer. Individual differences in subconscious motor control predicted by GABA concentration in SMA. Curr Biol, v. 20, n. 19, p. 1779 85, Oct 12 2010. ISSN 0960-9822.

[76] C.J. Stagg, V. Bachtiar, H. Johansen-Berg. The role of GABA in human motor learning. Curr Biol, v. 21, n. 6, p. 480-4, Mar 222011 ISSN 0960-9822.

[77] A. Floyer-Lea, M. Mlezinska, T. Kincses, P.M. Mattheuws. Rapid modulation of GABA concentration in human sensorimotor cortex during motor learning. J Neurophysiol, v. 95, n. 3, p. 1639-44, Mar 2006. ISSN 0022-3077 (Print) 0022-3077.

[78] I. Bar-Gad, G. Morris, H. Bergman. Information processing, dimensionality reduction and reinforcement learning in the basal ganglia. Prog Neurobiol, v. 71, n. 6, p. 439-73, Dec 2003. ISSN 03010082 (Print) 0301-0082.

[79] A. Bari; T.W. Robbins. Inhibition and impulsivity: behavioral and neural basis of response control. Prog Neurobiol, v. 108, p. 44-79, Sep 2013. ISSN 0301-0082.

[80] M.D. Humphries; T.J. Prescott. The ventral basal ganglia, a selection mechanism at the crossroads of space, strategy, and reward Prog Neurobiol, v. 90, n. 4, p. 385-417, Apr 2010. ISSN 0301-0082

[81] D. Plenz. When inhibition goes incognito: feedback interaction between spiny projection neurons in striatal function. Trends Neurosci, v. 26, n. 8, p. 436-43, Aug 2003. ISSN 0166-2236 (Print)

[82] E. Roberts. GABAergic malfunction in the limbic system resulting from an aboriginal genetic defect in voltage-gated Na+-channel SCN5A is proposed to give rise to susceptibility to schizophrenia. Advances in pharmacology (San Diego, Calif.), v. 54, p. 119, 2006 https://doi.org/10.1016/S1054-3589(06)54006-2.

[83] E. Roberts. Roles of GABA in neurons in information processing in the vertebrate CNS. Neuronal information transfer, p. 213-239, 1978.

[84] E. Roberts. Disinhibition as an organizing principle in the nervous system - the role of the GABA system. Application to neurologic and psychiatric disorders. In: (Ed.). GABA in nervous system function: Raven Press New York, 1976. p.515-539.

[85] E. Roberts. Failure of GABAergic inhibition: a key to local and global seizures. Adv Neurol, v. 44, p. 319-41, 1986. ISSN 00913952 (Print) 0091-3952.

[86] E. Roberts. Living systems are tonically inhibited, autonomous optimizers, and disinhibition coupled to variability generation is their major organizing principle: inhibitory command-control at levels of membrane, genome, metabolism, brain, and society. Neurochem Res, v. 16, n. 3, p. 409-21, Mar 1991. ISSN 0364-3190 (Print) 0364-3190.

[87] L. Jasmin, S.D. Rabkin, A. Granato, A. Boudah, P.T. Ohara. Analgesia and hyperalgesia from GABA-mediated modulation of the cerebral cortex. Nature, v. 424, n. 6946, p. 316-20, Jul 172003 ISSN 0028-0836.

[88] S.P. Hunt; P.W. Mantyh. The molecular dynamics of pain control. Nat Rev Neurosci, v. 2, n. 2, p. 83-91, Feb 2001. ISSN 1471-003X (Print) 1471-003x

[89] D.J. Nutt; A.L. Malizia. New insights into the role of the GABA (A)-benzodiazepine receptor in psychiatric disorder. Br J Psychiatry, v. 179, p. 390-6, Nov 2001. ISSN 0007-1250 (Print) 0007-1250.

[90] J. Bormann. The 'ABC' of GABA receptors. Trends Pharmacol Sci, v. 21, n. 1, p. 16-9, Jan 2000. ISSN 0165-6147 (Print) 0165-6147.

[91] E. Roberts. What do GABA neurons really do? They make possible variability generation in relation to demand. Exp Neurol, v. 93, n. 2 , p. 279-90, Aug 1986b. ISSN 0014-4886 (Print) 0014-4886.

[92] J. Ong; D.I. Kerr. Recent advances in GABAB receptors: from pharmacology to molecular biology. Acta Pharmacol Sin, v. 21, n. 2, p. 111-23, Feb 2000. ISSN 1671-4083 (Print) 1671-4083.

[93] S.J. Zhang; M.B. Jackson. GABA-activated chloride channels in secretory nerve endings. Science, v. 259, n. 5094, p. 531-4, Jan 22 1993. ISSN 0036-8075 (Print) 0036-8075.

[94] K.J. Staley; I. Mody. Shunting of excitatory input to dentate gyrus granule cells by a depolarizing GABAA receptor-mediated postsynaptic conductance. J Neurophysiol, v. 68, n. 1, p. 197-212, Jul 1992. ISSN 0022-3077 (Print) 0022-3077.

[95] N. Shyamaladevi, A.R. Jayakumar, R. Sujatha, V. Paul, E.H. Subramanian. Evidence that nitric oxide production increases $\gamma$ amino butyric acid permeability of blood-brain barrier. Brain research bulletin, v. 57, n. 2, p. 231-236, 2002. https://doi.org/10.1016/S0361-9230(01)00755-9.

[96] G.M. Knudsen, H.E. Poulsen, O.B. Paulson.. Blood-brain barrier permeability in galactosamine-induced hepatic encephalopathy. No evidence for increased GABA-transport. J Hepatol, v. 6, n. 2, p. 187-92, Apr 1988. ISSN 0168-8278 (Print) 0168-8278.

[97] M.L. Bassett, K.D. Mullen, B. Scholz, J.D.Fenstemacher, E.A. Jones. Increased brain uptake of gamma-aminobutyric acid in a rabbit model of hepatic encephalopathy. Gastroenterology, v. 98, n. 3, p. 747-57, Mar 1990. ISSN 0016-5085 (Print) 0016-5085.

[98] G.M. Haig, H.N. Bockbrader, D.L. Wesche, S.W. Boellner, D. Ouellet, R.R. Brouwn, et al. Single-dose gabapentin pharmacokinetics and safety in healthy infants and children. J Clin Pharmacol, v. 41, n. 5, p. 507-14, May 2001. ISSN 0091-2700 (Print) 00912700 . 
[99] A. Yildiz, C. Quetscher, S. Dharmadhikari, W. Chmielewski, B Glaubitz, T.S. Wilcke, et al. Feeling safe in the plane: neural mechanisms underlying superior action control in airplane pilot trainees-a combined EEG/MRS study. Hum Brain Mapp, v. 35, n. 10, p. 5040-51, Oct 2014. ISSN 1065-9471.

[100] L. Steenbergen, R. Sellaro, A.K. Stock, R. Beste, L. Colzato. $\gamma$ Aminobutyric acid (GABA) administration improves action selection processes: a randomised controlled trial. Scientific Reports, 2015a.

[101] A.K. Stock, M. Blaszkewicz, c. Beste. Effects of binge drinking on action cascading processes: an EEG study. Arch Toxicol, v. 88, n. 2, p. 475-88, Feb 2014. ISSN 0340-5761.

[102] L. Steenbergen, R. Sellaro, A.K. Stock, B. Verkuill, C. Beste, L.S. Colzato. Transcutaneous vagus nerve stimulation (tVNS) enhances response selection during action cascading processes. Eur Neuropsychopharmacol, v. 25, n. 6, p. 773-8, Jun 2015b. ISSN 0924-977x.

[103] V. Rizzo, A. Qiartarone, S. Bagnato, F. Battaglia, G. Majorana, P. Girlanda. Modification of cortical excitability induced by gabapentin: a study by transcranial magnetic stimulation. Neurol Sci, v. 22, n. 3, p. 229-32, Jun 2001. ISSN 1590-1874 (Print) 15901874.

[104] F. Verbruggen, D.W. Schneider, G.D. Logan. How to stop and change a response: the role of goal activation in multitasking.Journal of Experimental Psychology: Human Perception and Performance, $\quad$ v. $34, \quad$ n. $5, \quad$ p. 1212,2008 https://doi.org/10.1037/0096-1523.34.5.1212.

[105] F. Stahl; G. Dorner. Responses of salivary cortisol levels to stress-situations. Endokrinologie, v. 80, n. 2, p. 158-62, Oct 1982. ISSN 0013-7251 (Print) 0013-7251.

[106] D.H. Hellhammer, C. Heib, W. Hubert, L. Rolf. Relationships between salivary cortisol release and behavioral coping under examination stress. IRCS Medical Science: Psychology \& Psychiatry, v. 13,1985

[107] K.V. Jones, D.L. Copolov, K.H. Outch. Type A, test performance and salivary cortisol. Journal of Psychosomatic Research, v. 30, n. 6, 1986. ISSN 6.

[108] L. Martinek, K. Oberascher-Holzinger, S. Weishuhn, W Klimesch, H.H. Kerschbaum. Anticipated academic examinations induce distinct cortisol responses in adolescent pupils. Neuro Endocrinol Lett, v. 24, n. 6, p. 449-53, Dec 2003. ISSN 0172-780X (Print) 0172-780x.

[109] M. Toda, R. Den, S. Nagasawa, K. Kitamura, K. Morimoto Relationship between lifestyle scores and salivary stress markers cortisol and chromogranin A. Arch Environ Occup Health, v. 60, n. 5, p. 266-9, Sep-Oct 2005. ISSN 1933-8244 (Print) 1933-8244.

[110] D.T. O'Connor. Chromogranin: widespread immunoreactivity in polypeptide hormone producing tissues and in serum. Regul Pept v. 6, n. 3, p. 263-80, Jul 1983. ISSN 0167-0115 (Print) 0167-0115.

[111] J. Saruta, K. Tsukinoki, K. Sasaguri, H. Ishii, M. Yasuda, Y.R Osamura, et al. Expression and localization of chromogranin A gene and protein in human submandibular gland. Cells Tissues Organs, v. 180, n. 4 , p. 237-44, 2005. ISSN 1422-6405 (Print) $1422-$ 6405 .

[112] T. Kanehira, Y. Nakamura, K. Nakamura, K. Horie, N. Horie, K. Furugori, et al. Relieving occupational fatigue by consumption of a beverage containing gamma-amino butyric acid. J Nutr Sci Vitaminol (Tokyo), v. 57, n. 1, p. 9-15, 2011. ISSN 0301-4800.

[113] A.M. Abdou, S. Higashiguchi, K. Horie, M. Kim, H. Hatta, H. Yokogoshi. Relaxation and immunity enhancement effects of gamma-aminobutyric acid (GABA) administration in humans. Biofactors, v. 26, n. 3, p. 201-8, 2006. ISSN 0951-6433 (Print) 09516433.

[114] P. Yang, G. Cai, Y. Cai, J. Fei, G. Liu. Gamma aminobutyric acid transporter subtype 1 gene knockout mice: a new model for attention deficit/hyperactivity disorder. Acta biochimica et biophysica Sinica, v. 45, n. 7, p. 578-585, 2013. https://doi.org/10.1093/abbs/gmt043.

[115] R.A. Edden, D. Crocetti, H. Zhu, D.L. Gilbert, S.H. Mostofsky. Reduced GABA concentration in attention- deficit/hyperactivity disorder. Arch Gen Psychiatry, v. 69, n. 7, p. 750-3, Jul 2012. ISSN 0003-990x. 